\title{
Climate Change and Its Impact on Crop Productivity
}

\author{
Bilal Ahmad Lone ${ }^{1 *}$, Sameera Qayoom ${ }^{1}$, Purshotam Singh ${ }^{1}$, \\ Zahoor Ahmad Dar', Sandeep Kumar', N. A. Dar ${ }^{1}$, Asma Fayaz', Nazir Ahmad', \\ Lyaket $^{1}$, M. Iqbal Bhat ${ }^{1}$ and Gurdeep Singh ${ }^{1}$
}

${ }^{1}$ Sher-e-Kashmir University of Agricultural Sciences and Technology (SKUAST), Kashmir, India.

Authors' contributions

This work was carried out in collaboration between all authors. Author BAL designed the study. Author $S Q$ performed the statistical analysis. Authors SQ, PS and ZAD wrote the protocol and author SK wrote the first draft of the manuscript. Authors NAD and AF managed the analyses of the study. Authors Lyaket, MIB and GS managed the literature searches. All authors read and approved the final manuscript.

Article Information

DOI: 10.9734/BJAST/2017/34148

Editor(s):

(1) Borislav Banjac, Department of Field and Vegetable Crops, University of Novi Sad, Serbia.

Reviewers:

(1) Dennis Kyereh, Kwame Nkrumah University of Science and Technology, Ghana.

(2) Msafiri Y. Mkonda, Sokoine University of Agriculture, Tanzania.

(3) Ali Lardia Bougma, University of Ouagadougou, Burkina Faso. Complete Peer review History: http://www.sciencedomain.org/review-history/19491

Review Article

Received $16^{\text {th }}$ May 2017

Accepted 31 $1^{\text {st }}$ May 2017

Published $12^{\text {th }}$ June 2017

\begin{abstract}
The changing patterns in day to day weather situations, rising $\mathrm{CO}_{2}$ concentrations, rising sea level, increasing temperature is an indicative of the fact that climate change being encountered by the life of earth at present. Climate change is caused by natural and anthropogenic factors-the natural being due to the periodic tidal pulls exerted by the astronomical bodies on earth's atmosphere and the enhanced one's are due to Changes in the climate through past and present are being evidenced through tephrochronological, dendrochronological, paleonological and archaeological measurements.Climate change has an impact on entire ecosystem, the greatest being on agriculture. Increasing $\mathrm{CO}_{2}$ concentration increases photosynthetic rates in $\mathrm{C} 3$ plants, and reduces transpiration due to decreased stomatal aperture, thus increasing water use efficiency Elevated $\mathrm{CO}_{2}$ at $330 \mathrm{ppm}$ raised rice yields by $20 \%$ and further increase to $700 \mathrm{ppm}$ increased yield by $26.4 \%$. Increased yield is counteracted by a higher temperature that causes moisture stress, delays the maturity of crops due to increased senescence and reduction in grain filling period. Under warm temperature, $2^{\circ} \mathrm{C}$ above normal, decline in grain yiel d was to the tune of $8.4 \%$ in rice and $12.2 \%$ in
\end{abstract}


wheat. A decline in yield to the tune $12.1 \%$ and $8.9 \%$ in rice and maize has been reported with the decline in solar radiation by $10 \%$ from normal. A yield decline of about $13 \%$ has been reported with an increased exposure to UV radiations at $320 \mathrm{~nm}$ caused due to ozone depletion. On an average the crop climate models suggest a decline in productivity by $3-17^{\circ} \mathrm{C}$ with $2^{\circ} \mathrm{C}$ rise in temperature, suggesting future research to recognize the potential interactions of climatic variables to ameliorate the adverse influence of changing climate on agro ecosystems. Climate change is expected to adversely affect the sustainable development capabilities of most Asian developing countries by aggravating pressures on natural resources and the environment. Development of sustainable cities in Asia with fewer fossil fuel-driven vehicles and with more trees and greenery would have a number of co-benefits, including improved public health. (IPCC 2014). To overcome this we have to Increase crop diversity by inter-cropping and appropriate cropping systems/rotations/land use; Adopt land/water conservation agriculture methods suited to varied agro-climates, balanced use of biocides/chemicals; Increase carbon fixation in the soil by growing deep-rooted crops so as to decrease carbon foot - print; Use water judiciously: more crop/unit of water; Use less fossil fuels; Use more solar/wind sources of energy; Climate smart agriculture needs to be adopted for better tomorrow.

Keywords: Climate; crops; mitigation; carbon dioxide; temperature.

\section{HISTORICAL}

The history of earth's climate for the past $1,60,000$ years has been constructed through the analysis of ice and air bubbles that were trapped in the ice when it froze during the course of time. At the time of maximum glaciations, the global mean temperature was supposed to be 57 degree centigrade lower than the present. The lowering of the snow caps to the extent of 200$400 \mathrm{~m}$ was accounted for by a summer cooling of about 1.5 degrees. Following the little ice age, there was a marked recovery in temperature in early $20^{\text {th }}$ century. During the last century, earth's climate warmed up by 0.3-0.6 degrees. From the global picture of recent weather events, it looks as if the world climate has gone topsy turvy. During the last few years, it has rained at wrong times and at wrong places. The weather at many places is amazingly abnormal. Western and Central Europe has experienced wettest spring. The Alps got a new coat of snow during the month of May which is most unusual. In Eastern Queensland province of Australia, floods and subsequent severe droughts have brought havoc to the crops. In North-east Argentina, heavy rains and consequent floods caused heavy loss to cotton, rice and other crops. Heavy and unexpected snowfall in Britain and cyclones in Australia since December 20 this year can provide an indication of extreme variability of climate at present.

The Indian subcontinent provides ample evidences to suggest that the region experienced similar climatic anomalies in the past. Greater frequency of droughts with more number of consecutive drought years indicate a transition from colder to warmer periods although the analysis of rainfall series over the past two centuries do not suggest any significant trend.

\subsection{Facts Representing the Global Climate Change Trends}

Global average temperature has increased by $0.6 \mathrm{C}$ over $20^{\text {th }}$ century. Over the last 50 years, night temperature has increased by $0.2^{\circ} \mathrm{C}$ per decade. 1990's was the warmest decade and 1998 was the warmest year in last 1000 years in $\mathrm{N}$-hemisphere. There has been a reduction of two weeks in the annual duration of lake and river ice over $20^{\text {th }}$ century. Northern-Hemisphere spring and summer sea ice extent decreased by 10 to $15 \%$ since 1950 . There has been a $40 \%$ reduction in the late summer arctic sea ice thickness in recent decade. Global sea level increased by 10 to $20 \mathrm{~cm}$ in the $20^{\text {th }}$ century. The surface temperature of earth is projected to increase by $1.4^{\circ} \mathrm{C}$ to $5.8^{\circ} \mathrm{C}$ by 2100 . Atmospheric carbon dioxide levels will double the pre-industrial level, enough to increase the temperature by 3- 5 degree $C$ by the end of this century. The Intergovernmental Panel on Climate Change [1] has predicted sea level rise of 9 to 88 $\mathrm{cm}$ by the end of this century. The capacity of the ocean to absorb carbon dioxide has fallen from 27 to $24 \%$ between 2000 and 2007 .

\subsection{Physical Evidence for Climatic Change}

Evidence for climatic change is taken from a variety of sources that can be used to reconstruct 
past climates. Reasonably complete global records of surface temperature are available beginning from the mid-late 1800s. For earlier periods, most of the evidence is indirectclimatic changes are inferred from changes in indicators that reflect climate, such as vegetation, ice cores dendrochronology, sea level change, and glacial geology.

\subsection{Historical and Archaeological Evidence}

Climate change in the recent past may be detected by corresponding changes in settlement and agricultural patterns. Archaeological evidence, oral history and historical documents can offer insights into past changes in the climate. Climate change effects have been linked to the collapse of various civilisations.

\subsection{Glaciers}

Glaciers are among the most sensitive indicators of climate change advancing when climate cools (for example, during the period known as the Little Ice Age) and retreating when climate warms. Glaciers grow and shrink; Both contributing to natural variability and amplifying externally forced changes. A world glacier inventory has been compiled since the 1970s. Initially based mainly on aerial photographs and maps, this compilation has resulted in a detailed inventory of more than 100,000 glaciers covering a total area of approximately $240,000 \mathrm{~km}^{2}$ and, in preliminary estimates, for the recording of the remaining ice cover estimated to be around $445,000 \mathrm{~km}^{2}$. The World Glacier Monitoring Service collects data annually on glacier retreat and glacier mass balance. From this data, glaciers worldwide have been found to be shrinking significantly, with strong glacier retreats in the 1940s, stable or growing conditions during the 1920 s and 1970 s, and again retreating from the mid 1980s to present. Mass balance data indicate 17 consecutive years of negative glacier mass balance.

The most significant climate processes since the middle to late Pliocene (approximately 3 million years ago) are the glacial and interglacial cycles. The present interglacial period (the Holocene) has lasted about 11,700 years. Shaped by orbital variations, responses such as the rise and fall of continental ice sheets and significant sea-level changes helped create the climate. Other changes, including Heinrich events,
Dansgaard-Oeschger events and the Younger Dryas, however, illustrate how glacial variations may also influence climate without the forcing effect of orbital changes. Glaciers leave behind moraines that contain a wealth of material including organic matter that may be accurately dated - recording the periods in which a glacier advanced and retreated. Similarly, by tephrochronological techniques, the lack of glacier cover can be identified by the presence of soil or volcanic tephra horizons whose date of deposit may also be precisely ascertained.

\subsection{Vegetation}

A change in the type, distribution and coverage of vegetation may occur given a change in the change; This much is obvious. In any given scenario, a mild change in climate may result in increased precipitation and warmth, resulting in improved plant growth and the subsequent sequestration of airborne $\mathrm{CO}_{2}$. Larger, faster or more radical changes, however, may well result in vegetation stress, rapid plant loss and desertification in certain circumstances.

\subsection{Ice Cores}

Analysis of ice in a core drilled from a ice sheet such as the Antarctic ice sheet, can be used to show a link between temperature and global sea level variations. The air trapped in bubbles in the ice can also reveal the $\mathrm{CO}_{2}$ variations of the atmosphere from the distant past, well before modern environmental influences. The study of these ice cores has been a significant indicator of the changes in $\mathrm{CO}_{2}$ over many millennia, and continues to provide valuable information about the differences between ancient and modern atmospheric conditions.

\subsection{Dendrochronology}

Dendochronology is the analysis of tree ring growth patterns to determine the age of a tree. From a climate change viewpoint, however, Dendochronology can also indicate the climatic conditions for a given number of years. Wide and thick rings indicate a fertile, well-watered growing period, whilst thin, narrow rings indicate a time of lower rainfall and less-than-ideal growing conditions.

\subsection{Pollen Analysis}

Palynology is the study of contemporary and fossil palynomorphs, including pollen. Palynology 
is used to infer the geographical distribution of plant species, which vary under different climate conditions. Different groups of plants have pollen with distinctive shapes and surface textures, and since the outer surface of pollen is composed of a very resilient material, they resist decay. Changes in the type of pollen found in different sedimentation levels in lakes, bogs or river deltas indicate changes in plant communities; which are dependent on climate conditions.

\subsection{Insects}

Remains of beetles are common in freshwater and land sediments. Different species of beetles tend to be found under different climatic conditions. Given the extensive lineage of beetles whose genetic makeup has not altered significantly over the millennia, knowledge of the present climatic range of the different species, and the age of the sediments in which remains are found, past climatic conditions may be inferred.

\subsection{Sea Level Change}

Global sea level change for much of the last century has generally been estimated using tide gauge measurements collated over long periods of time to give a long-term average. More recently, altimeter measurements - in combination with accurately determined satellite orbits - have provided an improved measurement of global sea level change.

\section{CAUSES OF CLIMATE CHANGE}

Climate change is a change in the statistical distribution of weather over periods of time that range from decades to millions of years. It can be a change in the average weather or a change in the distribution of weather events around an average (for example, greater or fewer extreme weather events).

Natural variability is a characteristic of the global climate and occurs on a long and short term scale. Majority of climatologists believe that both long and short term fluctuations are not a random phenomena, rather these are organised events which are controlled by courses or energy sources either associated with the earth itself or with the planetary bodies of our solar system. There is a school of thoughts which attribute the fluctuations in climate to the periodical tidal pulls exerted by the astronomical bodies on the atmosphere of the earth in a similar fashion as on the oceans. Another group of investigators presume that the abnormal patterns in the atmosphere are produced by variations in the amount and quality of solar energy, the solar spectrum especially the ultra violet portion affects the ozone concentration. There are others who think that short term fluctuations in the climate are due $t \mathrm{El} \mathrm{Nino/} \mathrm{southern} \mathrm{oscillations} \mathrm{(ENSO).}$ Super imposed on these natural variations are the changes induced by human activities. The release of Green House Gases in the atmosphere is the basic cause of the climatic pattern.

According to several climatologists, the atmospheric circulation is a stochastic process which allows for the occurrence of irregular fluctuations resulting from the basic sluggish character of the atmosphere or some additional control. The additional control according to these scientists could be an extra terrestrial impulse or an inherent characteristic of the atmosphere which causes the circulation to switch abruptly from one regime to another.

The earth's climate is dynamic and always changing through a natural cycle. What the world is more worried about is that the changes that are occurring today have been speeded up because of man's activities. These changes are being studied by scientists all over the world who are finding evidence from tree rings, pollen samples, ice cores, and sea sediments. The causes of climate change can be divided into two categories - those that are due to natural causes and those that are created by man.

\subsection{Natural Causes}

There are a number of natural factors responsible for climate change.

Continental drift, Volcanic eruptions, The earth's tilt and Variation in the earth's orbital characteristics.

\subsection{Human Causes}

Anthropogenic factors are human activities that change the environment. In some cases the chain of causality of human influence on the climate is direct and unambiguous (for example, the effects of irrigation on local humidity), whilst in other instances it is less clear. Various hypotheses for human-induced climate change have been argued for many years. Presently the scientific consensus on climate change is that human activity is very likely the cause for the 
rapid increase in global average temperatures over the past several decades. Consequently, the debate has largely shifted onto ways to reduce further human impact and to find ways to adapt to change that has already occurred. Human activities including deforestation, emission of green house gases, changes in land use patterns etc [2].

Of most concern in these anthropogenic factors is the increase in $\mathrm{CO}_{2}$ levels due to emissions from fossil fuel combustion, followed by aerosols (particulate matter in the atmosphere) and cement manufacture. Other factors, including land use, ozone depletion, animal agriculture and deforestation, are also of concern in the roles they play - both separately and in conjunction with other factors - in affecting climate.

\subsubsection{The green house effect}

Most scientists agree the main cause of the current global warming trend is human expansion of the "greenhouse effect" - warming that result when the atmosphere traps heat radiating from Earth toward space.

Certain gases in the atmosphere behave like the glass on a greenhouse, allowing sunlight to enter, but blocking heat from escaping. Longlived gases, remaining semi-permanently in the atmosphere, which do not respond physically or chemically to changes in temperature, are described as "forcing" climate change whereas gases, such as water, which respond physically or chemically to changes in temperature are seen as "feedbacks."

Gases that contribute to the greenhouse effect include.

\subsubsection{Water vapour}

The most abundant greenhouse gas, but importantly, it acts as a feedback to the climate. Water vapour increases as the Earth's atmosphere warms, but so does the vapour. possibility of clouds and precipitation, making these some of the most important feedback mechanisms to the greenhouse effect.

\subsubsection{Carbon dioxide $\left(\mathrm{CO}_{2}\right)$}

A minor but very important component of the effect atmosphere, carbon dioxide is released through natural processes such as respiration and volcano eruptions and through human activities such as deforestation, land use changes, and burning fossil fuels. Humans have increased atmospheric $\mathrm{CO}_{2}$ concentration by a third since the Industrial Revolution began. This is the most important long-lived "forcing" of climate change.

\subsubsection{Methane}

A hydrocarbon gas produced both through natural sources and human activities, including the decomposition of wastes in landfills, agriculture, and especially rice cultivation, as well as ruminant digestion and manure management associated with domestic livestock. On a molecule-for-molecule basis, methane is a far more active greenhouse gas than carbon dioxide, but also one which is much less abundant in the atmosphere.

\section{$\underline{\text { 2.2.5 Nitrous oxide }}$}

A powerful greenhouse gas produced by soil cultivation practices, especially the use of commercial and organic fertilizers, fossil fuel combustion, nitric acid production, and biomass burning.

\subsubsection{Chlorofluorocarbons (CFCs)}

Synthetic compounds of entirely of industrial origin used in a number of applications, but now largely regulated in production and release to the atmosphere by international agreement for their ability to contribute to destruction of the ozone layer. They are also greenhouse gases.

\subsection{Consequences of Green House Effect}

The consequences of changing the natural atmospheric greenhouse are difficult to predict, but certain effects seem likely.

On average, Earth will become warmer. Some regions may welcome warmer temperatures, but others may not.

Warmer conditions will probably lead to more evaporation and precipitation overall, but individual regions will vary, some becoming wetter and others dryer.

A stronger greenhouse effect will warm the oceans and partially melt glaciers and other ice, increasing sea level. Ocean water also will expand if it warms, contributing further to sea level rise. Meanwhile, some crops and other plants may respond favourably to increased 
atmospheric $\mathrm{CO}_{2}$, growing more vigorously and using water more efficiently. At the same time, higher temperatures and shifting climate patterns may change the areas where crops grow best and affect the makeup of natural plant communities.

The climatic response to increasing green house gases has been assessed through various mathematical models. The surface air temperature due to $\mathrm{CO}_{2}$ doubling as simulated by a variety of general atmospheric circulation models yields warming of order $4.2^{\circ} \mathrm{C}$. The green house gases induced warming for the period 1950 to 2030 will be 1.5 and $6.1^{\circ} \mathrm{C}$. An average rate of increase of global temperature during the next century is projected as $0.3^{\circ} \mathrm{C}$ per decade with an uncertainty range of $0.2-0.3^{\circ} \mathrm{C}$. Two positive feedback effects of greenhouse effect are that higher surface temperature causes more evaporation and thus higher water vapour concentrations and water vapour itself is an infra red absorber. The second effect is that higher surface temperatures will lead to more melting of snow and ice cover on land and sea which will lead to greater absorption of solar energy instead of reflecting it back into space. On the other hand negative feedbacks include the possibility that a higher surface temperature may lead to cloudiness and thus reduce incoming solar radiation. The cloudiness effect could lead to further warming in some circumstances as the clouds will also decrease the infra red Heat loss from the surface.

\section{DEFORESTATION AND CLIMATE CHANGE}

Forests purify our air, preserve watersheds and Improve water quality and quantity, stabilize soil and prevent erosion, provide us with natural resources such as timber products and medicinal plants, and are home to many of the world's most endangered wildlife species. In addition, an estimated 1.6 billion people worldwide rely on forests for their livelihoods, with 60 million indigenous people depending on forests for their subsistence. Another critically important function of forests increasingly and widely acknowledged now is that they help to protect the planet from climate change by absorbing carbon dioxide $\left(\mathrm{CO}_{2}\right)$, a major greenhouse gas. Forests play a critical role in protecting the Earth by Regulating climate patterns, as the trees - trunks, branches and roots - and even soil absorb and store $\mathrm{CO} 2$, providing a natural reservoir for this GHG. In fact, the Earth's vegetation and soils currently contain the equivalent of approximately 7500 Giga tonnes (Gt) of $\mathrm{CO} 2$ - that is more carbon than is contained in all the remaining oil stocks on the planet and more than double the total amount of carbon currently in the atmosphere. However, when forests are destroyed or degraded by activities such as logging and conversion of forests land, they release large quantities of $\mathrm{CO}_{2}$ and other GHGs, and become a significant source of GHG emissions and contributor to climate change.

\section{OZONE AND CLIMATE CHANGE}

Anthropogenic activities release chlorofluro carbons (CFC's) which ultimately break down in the atmosphere above $25 \mathrm{~km}$ by photolysis that frees the highly reflective chlorine. The chlorine competes with nitrogen oxides for odd oxygen species including ozone and the result is an efficient catalytic destruction of ozone by chlorine until it is removed from the system as $\mathrm{HCl}$. At the present rates of emission of CFC's severe $\mathrm{O}_{3}$ reduction ranging from $15 \%$ near $30 \mathrm{~km}$ to $40 \%$ near $45 \mathrm{~km}$ will result. Since the thermal balance of atmosphere is maintained by $\mathrm{O}_{3}$ which absorbs the solar radiation, therefore the destruction of $\mathrm{O}_{3}$ would cool the stratosphere. For example a $50 \%$ reduction in ozone would cool the atmosphere by about $20^{\circ} \mathrm{C}$. Ozone modulates the solar and infrared flux incident on the troposphere. A reduction in stratospheric ozone would allow more sunlight to reach the surface and tend to warm it. This warming will be offset by reduced IR fluxes emitted by cooler atmosphere and also by reduced GHE. The ozone depletion will show its impact on the atmospheric dynamics. Reduced ozone has already started reducing atmospheric heating rates. There is evidence that in mid October, the lower stratosphere over Antarctica is now $5^{\circ} \mathrm{C}$ cooler than it was 15 years ago. A yield decline of about $13 \%$ has been reported with an increased exposure to UV radiations at $320 \mathrm{~nm}$ caused due to ozone depletion [3]. If the ozone layer in the atmosphere continues to be depleted in the atmosphere, then more UV-radiation will reach the ground level. For a 10\% reduction in ozone, the flux of biologically damaging UV-rays at the earth's surface will increase by $20 \%$. The incidence of cataract and skin cancer, particularly in fair skinned population will increase alarmingly. Non melanomic cancers are expected to increase by $40 \%$ for a $10 \%$ ozone depletion. 
Table 1. Percentage increases of soybean midday photosynthetic rates, biomass yield, and seed yield predicted across selected carbon dioxide concentration $\left[\mathrm{CO}_{2}\right]$ ranges associated with relevant benchmark points in time [23]

\begin{tabular}{|c|c|c|c|c|c|}
\hline \multirow[t]{3}{*}{ Period of time (years) } & \multicolumn{2}{|c|}{$\left[\mathrm{CO}_{2}\right]-M i d d a y$} & \multirow[t]{2}{*}{ Biomass photosynthesis } & \multirow[t]{2}{*}{ Seed yield } & \multirow{2}{*}{$\begin{array}{c}\text { Biomass } \\
\text { yield }\end{array}$} \\
\hline & Initial & Final & & & \\
\hline & \multicolumn{2}{|c|}{ (Nmd/mol) } & \multicolumn{3}{|c|}{ (\% increase over initial $\left.\left[\mathrm{CO}_{2}\right]\right)$} \\
\hline IA-1700 & 200 & 270 & 38 & 33 & 24 \\
\hline $1700-1973$ & 270 & 330 & 19 & 16 & 12 \\
\hline $1973-2073 ?^{2}$ & 330 & 660 & 50 & 41 & 31 \\
\hline
\end{tabular}

Table 2. Seed yield, components of yield, total above-ground biomass and harvest index of soybean grown at two $\mathrm{CO}_{2}$ concentrations and three temperatures in 1987 [24]

\begin{tabular}{lllllll}
\hline $\begin{array}{l}\mathbf{C O}_{2} \text { conc. } \\
(\boldsymbol{\mu ~ m o l} / \mathbf{m o l})\end{array}$ & $\begin{array}{l}\text { Day/night } \\
\text { temperature } \\
\left({ }^{(} \mathbf{C}\right)\end{array}$ & $\begin{array}{l}\text { Grain } \\
\text { yield } \\
\text { (g/plant) }\end{array}$ & $\begin{array}{l}\text { Seed/plant } \\
\text { (no./plant) }\end{array}$ & $\begin{array}{l}\text { Seed mass } \\
\text { (mg/seed) }\end{array}$ & $\begin{array}{l}\text { Above- } \\
\text { ground } \\
\text { biomass } \\
\text { (g/plant) }\end{array}$ & $\begin{array}{l}\text { Harvest } \\
\text { index }\end{array}$ \\
\hline 330 & $26 / 19$ & 9.0 & 44.7 & 202 & 17.1 & 0.53 \\
330 & $31 / 24$ & 10.1 & 52.1 & 195 & 19.8 & 0.51 \\
330 & $36 / 29$ & 10.1 & 58.9 & 172 & 22.2 & 0.45 \\
660 & $26 / 19$ & 13.1 & 58.8 & 223 & 26.6 & 0.49 \\
660 & $31 / 24$ & 12.5 & 63.2 & 198 & 27.6 & 0.45 \\
660 & $36 / 29$ & 11.6 & 70.1 & 165 & 26.5 & 0.44 \\
\hline
\end{tabular}

Table 3. For soybean, leaf blade soluble protein expressed on a leaf blade area basis and percentage rubisco protein expressed on a leaf blade soluble protein basis for 34-day-old soybean plants grown under a wide range of $\mathrm{CO}_{2}$ concentrations. $[25,26]$. For rice, leaf nitrogen content expressed on a leaf area basis and percentage rubisco protein expressed on a leaf soluble protein basis for 75-day-old rice plants grown under a wide range of $\mathrm{CO}_{2}$ concentrations $[27,28]$

\begin{tabular}{llllll}
\hline & Soybean & & & Rice & \\
\hline $\begin{array}{l}\mathbf{C O}_{2} \text { growth } \\
\text { concentration } \\
(\mu \mathrm{mol} / \mathrm{mol})\end{array}$ & $\begin{array}{l}\text { Leaf } \\
\text { soluble } \\
\text { protein. } \\
\left(\mathbf{g} / \mathbf{m}^{2}\right)\end{array}$ & $\begin{array}{l}\text { Rubisco } \\
\text { protein } \\
(\%)\end{array}$ & $\begin{array}{l}\mathbf{C O}_{2} \text { growth } \\
\text { concentration } \\
\left(\mu \text { mol } / \mathbf{m o l}^{2}\right)\end{array}$ & $\begin{array}{l}\text { Leaf } \\
\text { nitrogen } \\
\text { protein } \\
\left.\text { mol } / \mathbf{m}^{2}\right)\end{array}$ & $\begin{array}{l}\text { Rubisco } \\
\text { protein } \\
(\%)\end{array}$ \\
\hline 160 & 2.5 & 56 & 160 & 95 & 62 \\
220 & 3.2 & 54 & 250 & 90 & 59 \\
280 & 2.6 & - & 330 & 81 & 54 \\
330 & 2.3 & 57 & 500 & 62 & 49 \\
660 & 2.3 & 54 & 660 & 78 & 43 \\
990 & 2.3 & 55 & 900 & 64 & 42 \\
\hline
\end{tabular}

Table 4. Grain yield, components of yield, total above-ground biomass and harvest index of rice subambient and superambient $\mathrm{CO}_{2}$ concentration experiments conducted in 1987 [29-33]

\begin{tabular}{llllllll}
\hline $\mathbf{C O}_{2}$ & Temperature & $\begin{array}{l}\text { Grain } \\
\text { yield }\end{array}$ & $\begin{array}{l}\text { Panicle/ } \\
\text { plant }\end{array}$ & $\begin{array}{l}\text { Filled } \\
\text { grain }\end{array}$ & $\begin{array}{l}\text { Grain } \\
\text { mass }\end{array}$ & Biomass & $\begin{array}{l}\text { Harvest } \\
\text { index }\end{array}$ \\
\cline { 1 - 2 } & ${ }^{\circ} \mathbf{C}$ & $\mathbf{M g} / \mathbf{h a}$ & no./plant & no./panicle & $\mathbf{m g} / \mathbf{s e e d}$ & $\mathbf{g} /$ plant & \\
\hline 160 & $31 / 31 / 27$ & $3.4 \mathrm{c}^{2}$ & $3.6 \mathrm{c}$ & $24.8 \mathrm{a}$ & $17.0 \mathrm{a}$ & $4.0 \mathrm{c}$ & $0.36 \mathrm{a}$ \\
250 & $31 / 31 / 27$ & $4.1 \mathrm{c}$ & $4.8 \mathrm{bc}$ & $20.8 \mathrm{a}$ & $18.2 \mathrm{a}$ & $5.1 \mathrm{bc}$ & $0.34 \mathrm{a}$ \\
330 & $31 / 31 / 27$ & $4.8 \mathrm{bc}$ & $5.7 \mathrm{ab}$ & $21.0 \mathrm{a}$ & $17.6 \mathrm{a}$ & $6.3 \mathrm{ab}$ & $0.34 \mathrm{a}$ \\
500 & $31 / 31 / 27$ & $6.8^{3}$ & 7.3 & 23.0 & 18.1 & 9.8 & 0.30 \\
660 & $31 / 31 / 27$ & $6.6 \mathrm{ab}$ & $6.5 \mathrm{ab}$ & $25.0 \mathrm{a}$ & $17.8 \mathrm{a}$ & $8.4 \mathrm{a}$ & $0.35 \mathrm{a}^{4}$ \\
900 & $31 / 31 / 27$ & $7.3 \mathrm{a}$ & $7.4 \mathrm{a}^{4}$ & $24.8 \mathrm{a}$ & $17.8 \mathrm{a}$ & $8.2 \mathrm{a}$ & $0.39 \mathrm{a}$ \\
\hline
\end{tabular}




\section{CLIMATE CHANGE AGROECOSYSTEMS}

By now it is very clear that the atmosphere is being constantly enriched with $\mathrm{CO}_{2}$ and is warmed up. However what else less clear is how the expected rise in $\mathrm{CO}_{2}$ level and air temperature will increase to affect the plant processes. If $\mathrm{LAl}$ increases with elevated $\mathrm{CO}_{2}$ concentrations, the ET is expected to rise with further increase in temperature because increased temperature is associated with greater vapour pressure deficits, hence greater moisture stress [4]. The occurrence of moisture stress during critical stages of crops like flowering and grain filling may result in steep reduction in post anthesis, photosynthesis and grain yield. Higher temperature also accelerates plant development and shortens the growth period. $\mathrm{CO}_{2}$ increase may affect the crop productivity directly and indirectly. Effects are both positive and negative. Under warm temperature, $2^{\circ} \mathrm{C}$ above normal, decline in grain yield was to the tune of $8.4 \%$ in rice and $12.2 \%$ in wheat [5].

\subsection{Direct Positive Effects}

It has been proved experimentally that for single leaf photosynthesis rate increases with increased $\mathrm{CO}_{2}$ level especially in $\mathrm{C}_{3}$ plants. When these experiments were extended to crop levels, it was found that increased $\mathrm{CO}_{2}$ to 600ppm increased the number of tillers and branches and hence greater solar radiation interception and resulting about $25 \%$ that increased $\mathrm{CO}_{2}$ reduced transpiration due to decreased stomata aperture and may result in higher WUE. Since those results were obtained from studies conducted in leaf chambers, green houses and growth chambers where the other environmental factors were controlled at a desired level, these may not be applicable under realistic situations.

\section{DIRECT NEGATIVE EFFECTS}

The increased LAI may result in self shading and thus reduces the net assimilation rate. It has been found that in northern India, the incident PAR always remains below 1600 microEm $^{-2} \mathrm{~s}^{-1}$ in winter and it was found that this PAR is not adequate to saturate the present day available canopy of most of the winter season crops at 330 ppm $\mathrm{CO}_{2}$ concentration. Increased $\mathrm{CO}_{2}$ results in higher LAl thus higher transpiring surface is available which might compensate the increased WUE on per plant basis.

\section{INDIRECT NEGATIVE EFFECTS}

\subsection{Crop Phenology}

There may be about $6-8 \%$ reduction in maturity duration for each $1^{\circ} \mathrm{C}$ rise in temperature. In wheat, for each ${ }^{\circ} \mathrm{C}$ rise in temperature, the reduction of about 5 days flowering date and 4 days from flowering to maturity has been recorded. Increased temperature during critical periods of crop development result in accelerated leaf senescence, decline in canopy photosynthesis and forced maturity in winter cereal crops.

\subsection{Yield}

Increased temperature by $1-2^{\circ} \mathrm{C}$ above mean of $17^{\circ} \mathrm{C}$ during grain filling period reduces the grain yield due to increased rate of senescence of flag leaf and reduction in grain filling period. Increased yield is counteracted by a higher temperature that causes moisture stress, delays the maturity of crops due to increased senescence and reduction in grain filling period [6].

\subsection{The Effects of Global Change on Soil Conditions in Relation to Plant Growth and Food Production}

The main potential changes in soil-forming factors (forcing variables) directly resulting from global change would be in organic matter supply from biomass, soil temperature regime and soil hydrology, the latter because of shifts in rainfall zones as well as changes in potential evapotranspiration important changes include:

1. A gradual, continuing rise in atmospheric $\mathrm{CO}_{2}$ concentration entailing increased photosynthetic rates and water-use efficiencies of vegetation and crops, hence increases in organic matter supplies to soils.

2. Minor increases in soil temperatures in the tropics and subtropics; moderate increases and extended periods in which soils are warm enough for microbial activity (warmer than about $5^{\circ} \mathrm{C}$ ) in temperate and cold climates, parallel to the changes in air temperatures and vegetation zones [7].

3. Minor increases in evapotranspiration in the tropics to major increases in high latitudes caused both by temperature 
increase and by extension of the growing period.

4. Increases in amount and in variability of rainfall in the tropics; Possible decrease in rainfall in a band in the subtropics poleward of the present deserts; minor increases in amount and variability in temperate and cold regions. Peak rainfall intensities could increase in several regions.

5. A gradual sea-level rise causing deeper and longer inundation in river and estuary basins and on levee back slopes, and brackish-water inundation leading to encroachment of vegetation that accumulates pyrite in soils near the coast:

Biomass production under climate change

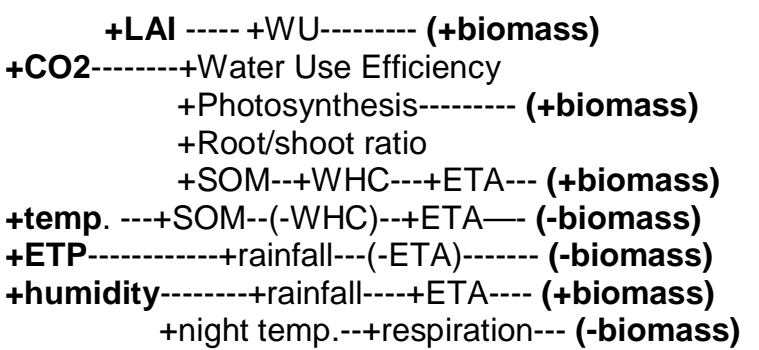

+cloudiness------- (-radiation) ----(-photosynthesis) - --- (-biomass)

(Hillel,1998)

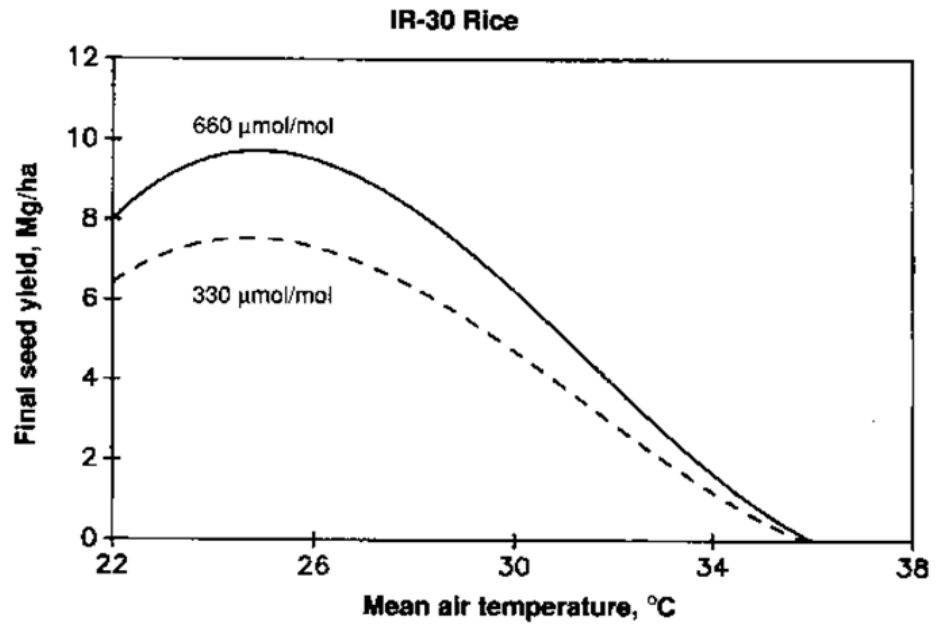

Fig. 1.Rice seed yield vs. weighted mean day/night air temperature for plants grown to maturity in $\mathrm{CO}_{2}$ concentrations of 330 and $660 \mu \mathrm{mol} / \mathrm{mol}$ in five separate experiments

Table 5. Effect of whole-plant warming on the rate of total dry matter and nitrogen accumulation, between days 10 and 20 after anthesis, in the grains of four cultivars of wheat

\begin{tabular}{llll}
\hline Cultivar & Treatment & \multicolumn{2}{c}{ Rate of increase (mg/grain/day) } \\
\cline { 3 - 4 } & & Total dry matter & N content \\
\hline AUS 22645 & C & $1.94 \pm 09$ & $0.03 \pm 002$ \\
& W & $2.07 \pm 07(107)$ & $0.48+003(160)$ \\
Kite & C & $1.72+15$ & $0.027 \pm 004$ \\
& W & $2.28 \pm 17(133)$ & $0.043 \pm 003(159)$ \\
Sonora & C & $1.65 \pm 18$ & $0.034 \pm 009$ \\
& W & $2.06 \pm 19(125)$ & $0.051 \pm 009(150)$ \\
WW15 & C & $1.89 \pm 20$ & $0.037 \pm 005$ \\
& W & $2.37 \pm 20(125)$ & $0.053+005(143)$ \\
\hline
\end{tabular}


Table 6. Effects of elevated surface-level UV-B radiation or $\mathrm{O}_{3}$, on crops

\begin{tabular}{ll}
\hline Plant characteristic & Effect of elevated \\
\cline { 2 - 2 } & UV-B \\
\hline Photosynthesis & Reduced in many $\mathrm{C}_{3}$ and $\mathrm{C}_{4}$ species (at low light intensities) \\
Leaf conductance & Reduced (at low light intensities) \\
Water-use efficiency & Reduced in most species \\
Leaf area & Reduced in many species \\
Specific leaf weight & Increased in many species \\
Crop maturation rate & Not affected \\
Flowering & Inhibited or stimulated \\
\hline
\end{tabular}

Table 7. Adverse effects of UV radiation on crop growth and/or productivity: A select summary

\begin{tabular}{|c|c|c|c|}
\hline Species & Exposure duration & Variable & Effect \\
\hline $\begin{array}{l}\text { Barley (spring) } \\
\text { (Hordeum } \\
\text { vulgare) }\end{array}$ & $\begin{array}{l}97,198 \text { and } 98 \text { days } \\
\text { during } 3 \text { growing seasons }\end{array}$ & $\begin{array}{l}\text { Seed } \\
\text { weight }\end{array}$ & $0-13 \%$ reduction \\
\hline Cotton & 124 days & $\begin{array}{l}\text { Lint } \\
\text { weight }\end{array}$ & Predicted loss of $19 \%$ \\
\hline Cotton & 119 days & $\begin{array}{l}\text { Lint } \\
\text { weight }\end{array}$ & Predicted loss of $11 \%$ \\
\hline $\begin{array}{l}\text { Rape (spring) } \\
\text { (Brassica } \\
\text { napus) }\end{array}$ & $\begin{array}{l}89,113 \text { and } 84 \text { days } \\
\text { during } 3 \text { growing seasons }\end{array}$ & $\begin{array}{l}\text { Seed } \\
\text { weight }\end{array}$ & $9.4-16 \%$ reduction \\
\hline Rape (spring) & $\begin{array}{l}89,113 \text { and } 84 \text { days } \\
\text { during } 3 \text { growing seasons }\end{array}$ & $\begin{array}{l}\text { Seed } \\
\text { weight }\end{array}$ & $12-27 \%$ reduction \\
\hline $\begin{array}{l}\text { Rice (Oryza } \\
\text { sativa) }\end{array}$ & 5 days/week, 15 weeks & $\begin{array}{l}\text { Seed } \\
\text { weight }\end{array}$ & $12-21 \%$ reduction \\
\hline $\begin{array}{l}\text { Soybean } \\
\text { (Glycine max) }\end{array}$ & 69 days & $\begin{array}{l}\text { Seed } \\
\text { yield }\end{array}$ & From $8 \%$ to $41 \%$ \\
\hline Soybean & $\begin{array}{l}13 \text { weeks, } 2 \text { growing } \\
\text { seasons }\end{array}$ & $\begin{array}{l}\text { Seed } \\
\text { yield }\end{array}$ & $\begin{array}{l}12-5 \% \text { reduction vs. charcoal-filtered } \\
\text { air, averaged over cultivars. Intercultivar } \\
\text { differences as great as the ozone effect. }\end{array}$ \\
\hline Soybean & 84 days & $\begin{array}{l}\text { Seed } \\
\text { yield }\end{array}$ & 15.8 and $29 \%$ reduction \\
\hline Soybean & $\begin{array}{l}\text { Four } 31 \text { day periods,! } \\
\text { growing season }\end{array}$ & $\begin{array}{l}\text { Seed } \\
\text { yield }\end{array}$ & $\begin{array}{l}30-56 \% \text { reduction vs. charcoal-filtered } \\
\text { air (control). most loss in mid to late } \\
\text { growth stage }\end{array}$ \\
\hline Soybean & About 90 days & $\begin{array}{l}\text { Seed } \\
\text { yield }\end{array}$ & Predicted loss of $10 \%$ \\
\hline $\begin{array}{l}\text { Wheat (winter) } \\
\text { (Triticum } \\
\text { aestivum) }\end{array}$ & 109 days & $\begin{array}{l}\text { Seed } \\
\text { weight }\end{array}$ & No effect \\
\hline Wheat (winter) & $\begin{array}{l}39 \text { and } 40 \text { days during } 2 \\
\text { growing seasons, } 5 \\
\text { days/week, } 4 \mathrm{~h} / \text { day }\end{array}$ & $\begin{array}{l}\text { Seed } \\
\text { weight }\end{array}$ & $\begin{array}{l}\text { Exposures during anthesis reduced } \\
\text { yield }\end{array}$ \\
\hline
\end{tabular}

\subsection{The $\mathrm{Co}_{2}$ Fertilization Effect}

Plant photosynthetic rates generally increase linearly with light across relatively low ranges of light intensity, and then the rates decelerate until they reach an asymptotic maximum. Because of crowding and shading of many leaves, most crop canopies do not reach light saturation at full sunlight; That is, they would be able to respond to light levels well beyond full solar irradiance. Likewise, crop photosynthetic rates respond to increasing levels of $\mathrm{CO}_{2}$ but then level off at higher concentration (around 700 micro $\mathrm{mol} / \mathrm{mol}$ or greater, depending upon species and other factors). However, leaf photosynthesis usually increases with temperature up to some maximum value, and then declines. Furthermore, 
temperature affects not only photosynthesis, but also respiration, growth, development phases and reproductive processes.

$\mathrm{CO}_{2}$ concentration increases photosynthetic rates in C3 plants, and reduces transpiration due to decreased stomatal aperture, thus increasing water use efficiency (Allen, 2004). Elevated $\mathrm{CO}_{2}$ at $330 \mathrm{ppm}$ raised rice yields by $20 \%$ and further increase to $700 \mathrm{ppm}$ increased yield by $26.4 \%[8]$.

Elevated $\mathrm{CO}_{2}$ may have some effects on crop phenology, although stages of development are governed primarily by temperature, time and photoperiod. If dates of planting were to be changed because of the greenhouse effect, then phenological timing of plants could be affected. For example, higher temperatures could decrease yields by decreasing the duration of the grain-filling period or changes in photoperiod could shorten or lengthen the vegetative stage.

Reproductive biomass growth as well as vegetative biomass growth are usually increased by elevated $\mathrm{CO}_{2}$. However, the harvest index, or the ratio of seed yield to above-ground biomass yield, is typically lower under elevated $\mathrm{CO}_{2}$ conditions $[9,10]$, which may also be evidence of the lack of capacity to utilize completely the more abundant photoassimilate.

Under elevated $\mathrm{CO}_{2}$ stomatal conductance in most species will decrease which may result in less transpiration per unit leaf area. However, leaf area index of some crops may also increase. The typical $40 \%$ reduction in stomatal conductance induced by a doubling of $\mathrm{CO}_{2}$ has generally resulted in only a $10 \%$ (or less) reduction in crop canopy water use in chamber or field experimental conditions. Actual changes in crop evapotranspiration will be governed by the crop energy balance, as mitigated by stomatal conductance, leaf area index, crop structure and any changing meteorological factors.

Water-use efficiency (WUE) (ratio of $\mathrm{CO}_{2}$ uptake to evapotranspiration) will increase under higher $\mathrm{CO}_{2}$ conditions. This increase is caused more by increased photosynthesis than it is by a reduction of water loss through partially closed stomata. Thus, more biomass can be produced per unit of water used, although a crop would still require almost as much water from sowing to final harvest. If temperatures rise, however, the increased WUE caused by the $\mathrm{CO}_{2}$ fertilization effect could be diminished or negated, unless planting dates can be changed to more favourable seasons.

Baker et al. [11] showed that soybean leaf photosynthetic rates were higher for plants grown at 660 than at $330 \mathrm{micromol} / \mathrm{mol} \mathrm{CO}_{2}$ when measured at common intercellular $\mathrm{CO}_{2}$ concentrations. Furthermore, [12] measured rubisco activity and amount in leaves of soybean grown in $\mathrm{CO}_{2}$ concentrations of $160,220,280$, 330,660 and $990 \mathrm{micro} \mathrm{mol} / \mathrm{mol}$. They found that rubisco activity was almost constant at 1.0 micro $\mathrm{mol} \mathrm{CO} / \mathrm{min} / \mathrm{mg}$ soluble protein across this $\mathrm{CO}_{2}$ treatment range. Leaf soluble protein was nearly constant at about $2.4 \mathrm{~g} / \mathrm{m}^{2}$ with $55 \%$ being rubisco protein. Specific leaf weight increased across the 160 to $990 \mathrm{micromol} / \mathrm{mol}^{\mathrm{CO}} \mathrm{CO}_{2}$ concentration range, so that the rubisco activity on a leaf dry weight basis decreased.

Growth of plants under elevated $\mathrm{CO}_{2}$ results in changes in partitioning of photoassimilates to various plant organs over time In soybean, elevated $\mathrm{CO}_{2}$ generally promoted greater carbon (dry matter) partitioning to the supporting structure (stems, petioles and roots) than to the leaf laminae during vegetative stages of growth [13]. During reproductive stages, there tended to be lower relative partitioning to reproductive growth (pods) by plants under elevated $\mathrm{CO}_{2}$.

Soybean seed yield was always increased by elevated $\mathrm{CO}_{2}$ [14] summarized the photosynthetic, biomass and seed yield responses of several experiments rectangular hyperbola model using data normalized to responses obtained at $330 \mu \mathrm{mol} / \mathrm{mol}$. The values of $K_{m}, Y_{\max }$ and $Y_{i}$ parameters for relative photosynthetic rates were $279 \mu \mathrm{mol} / \mathrm{mol}, 3.08$ and -0.68 , respectively, for relative biomass yield were $182 \mu \mathrm{mol} / \mathrm{mol}, \quad 3.02$ and -0.91 , respectively, and for relative seed yield were 141 $\mu \mathrm{mol} / \mathrm{mol}, 2.55$ and -0.76 , respectively. This model was used to project yields across several ranges of atmospheric $\mathrm{CO}_{2}$ concentration increases. For a doubling of $\mathrm{CO}_{2}$ this model predicted a $32.2 \%$ increase in soybean grain yield and a $42.7 \%$ increase in biomass. The ratio of these two numbers, 1.322/1.427 $=0.926$, gives the fraction of the harvest index expected under doubled $\mathrm{CO}_{2}$ in comparison with ambient $\mathrm{CO}_{2}$. 
Across a relatively wide temperature range from $25 / 18 / 21$ to $37 / 30 / 34{ }^{\circ} \mathrm{C}$, [15] found a broad temperature optimum for biomass production in the mid-temperature ranges. Plants grown at $40 / 33 / 37^{\circ} \mathrm{C}$ were near the upper temperature limit for survival. High temperature spikelet sterility of rice is induced almost exclusively on the day of anthesis [16] when temperatures greater than $3^{\circ} \mathrm{C}$ for more than one hour induce a high percentage of sterility [17]. In the $40 / 33 / 37^{\circ} \mathrm{C}$ treatments, plants in the $330 \mu$ $\mathrm{mol} / \mathrm{mol} \mathrm{CO}_{2}$ chamber died during internode elongation whereas plants in the $660 \mu \mathrm{mol} / \mathrm{mol}$ chamber produced small, abnormally shaped panicles that were sterile [18]. Therefore, elevated $\mathrm{CO}_{2}$ may slightly increase the maximum temperature at which rice plants can survive.

At both $\mathrm{CO}_{2}$ levels, grain yield was highest in the $28 / 21 / 25^{\circ} \mathrm{C}$ treatment followed by a decline to zero yield in the $40 / 33 / 37{ }^{\circ} \mathrm{C}$ treatment The $\mathrm{CO}_{2}$ enrichment from 330 to $660 \mu \mathrm{mol} / \mathrm{mol}$ increased yield by increasing the number of panicles per plant, whereas the number of filled grains per panicle and individual seed mass were less affected. Temperature effects on yield and yield components were highly significant. The number of panicles per plant increased while the number of filled grains per panicle decreased sharply with increasing temperature treatment. Individual seed mass was stable at moderate temperatures but tended to decline at temperature treatments above $34 / 27 / 31^{\circ} \mathrm{C}$. Final above-ground biomass and harvest index were increased by $\mathrm{CO}_{2}$ enrichment while harvest index declined sharply with increasing temperature. Notably, there were no significant $\mathrm{CO}_{2} \times$ temperature interaction effects on yield, yield components, or final above-ground biomass

\subsection{Effects of Higher Day and Night Temperatures on Yield}

Gaseous emissions from human activities are substantially increasing the concentrations of atmospheric greenhouse gases, particularly carbon dioxide, methane, chlorofluorocarbons and nitrous oxides. Global circulation models predict that these increased concentrations of greenhouse gases will increase average world temperature. Under the business-as-usual scenario of the Intergovernmental Panel on Climate Change (IPCC), global mean temperatures will rise $0.3^{\circ} \mathrm{C}$ per decade during the next century with an uncertainty of 0.2 to $0.5 \%$ [19]. Thus global mean temperatures should be $1^{\circ} \mathrm{C}$ above the present values by 2025 and $3^{\circ} \mathrm{C}$ above the present value by 2100 . Although global circulation models do not all agree as to the magnitude, most predict greenhouse warming. There is also general agreement that global warming will be greater at higher latitudes than in the tropics. Different global circulation models have predicted that global warming effects will vary diurnally, seasonally and with altitude.

It is also possible that there will be an autocatalytic component to global warming. Photosynthesis and respiration of plants and microbes increase with temperature, especially in temperate latitudes. As respiration increases more with increased temperature than does photosynthesis, global warming is likely to increase the flux of carbon dioxide to the atmosphere which would constitute a positive feedback to global warming.

In experiments under controlled conditions from 25 to $35^{\circ} \mathrm{C}$, mean grain weight declined $16 \%$ for each $5^{\circ} \mathrm{C}$ increase in temperature [20]. In pot experiments, grain yield decreased by $17 \%$ for each $5^{\circ} \mathrm{C}$ rise. For every $1^{\circ} \mathrm{C}$ rise in temperature, there is a depression in grain yield by 8 to $10 \%$, mediated through 5 to $6 \%$ fewer grains and 3 to $4 \%$ smaller grain weight.

Reduction of grain weight by heat stress may be explained mostly by effects of temperature on rate and duration of grain growth. As temperature increased from $15 / 10^{\circ} \mathrm{C}$ to $21 / 16{ }^{\circ} \mathrm{C}$, duration of grain filling was reduced from 60 to 36 days and grain growth rate increased from 0.73 to 1.49 $\mathrm{mg} / \mathrm{grain} /$ day with a result of minimal influence on grain weight at maturity. Further increase in temperature from $21 / 16{ }^{\circ} \mathrm{C}$ to $30 / 25^{\circ} \mathrm{C}$ resulted in decline in grain filling during 36 to 22 days with a minimal increase in grain growth rate from 1.49 to $1.51 \mathrm{mg} / \mathrm{grain} /$ day. Thus, mature grain weight was significantly reduced at the highest temperature.

\subsection{Adverse Effects of Elevated Levels of Ultraviolet (Uv)-B Radiation and Ozone $\left(\mathrm{O}_{3}\right)$ on Crop Productivity}

Surface-level ultraviolet (UV)-B radiation (280$320 \mathrm{~nm}$ ) and ozone $\left(\mathrm{O}_{3}\right)$ are components of the global climate and any increases in their levels can lead to adverse effects on crop growth and productivity on a broad geographic scale. Possible increases in surface UV-B radiation are attributed to the depletion of the beneficial stratospheric $\mathrm{O}_{3}$ layer. On the other hand, 
increases in surface-level $\mathrm{O}_{3}$ that in many regions are largely the result of photochemical oxidant pollution, are also part of the general increase in the concentrations of the so-called 'greenhouse' gases (e.g., carbon dioxide, $\mathrm{CO}_{2}$; Methane, $\quad \mathrm{CH}_{4} ; \quad$ nitrous oxide, $\mathrm{N}_{2} \mathrm{O}$; Chlorofluorocarbons, CFCs) that may lead to global warming. In the context of climate change, it is therefore important to maintain a holistic view and recognize that UV-B and $\mathrm{O}_{3}$ levels at the surface are only parts of the overall system of atmospheric processes and their products.

\section{SOLAR IRRADIANCE}

It's reasonable to assume that changes in the sun's energy output would cause the climate to change, since the sun is the fundamental source of energy that drives our climate system. Indeed, studies show that solar variability has played a role in past climate changes. For example, a decrease in solar activity is thought to have triggered the Little Ice Age between approximately 1650 and 1850, when Greenland was largely cut off by ice from 1410 to the 1720 s and glaciers advanced in the Alps. A decline in yield to the tune $12.1 \%$ and $8.9 \%$ in rice and maize has been reported with the decline in solar radiation by $10 \%$ from normal [21].

But several lines of evidence show that current global warming cannot be explained by changes in energy from the sun:

- Since 1750, the average amount of energy coming from the Sun either remained constant or increased slightly.

- If the warming were caused by a more active sun, then scientists would expect to see warmer temperatures in all layers of the atmosphere. Instead, they have observed a cooling in the upper atmosphere, and a warming at the surface and in the lower parts of the atmosphere. That's because greenhouse gasses are trapping heat in the lower atmosphere.

- Climate models that include solar irradiance changes can't reproduce the observed temperature trend over the past century or more without including a rise in greenhouse gases.

\section{1 $\mathrm{CO}_{2} /$ Uv-B \& Temperature Interactions}

A $25 \%$ increase in UV-B at $340 \mathrm{ppm} \mathrm{CO}_{2}$ changed sunflower and maize dry weights $(\mathrm{W})$ by
-14 and $-24 \%$, respectively (compared to ambient controls). The same UV-B increment combined with $\mathrm{a}+2^{\circ} \mathrm{C}$ temperature change altered $\mathrm{W}$ by $+5 \%$ in sunflower and $+31 \%$ in maize. Adding a doubled $\mathrm{CO}_{2}$ concentration to the elevated UV and temperature regime altered $\mathrm{W}$ by +19 and $+32 \%$ for sunflower and maize, respectively [22].

In the long run, the climatic change could affect agriculture in several ways:

- productivity, in terms of quantity and quality of crops.

- agricultural practices, through changes of water use (irrigation) and agricultural inputs such as herbicides, insecticides and fertilizers.

- environmental effects, in particular in relation of frequency and intensity of soil drainage (leading to nitrogen leaching), soil erosion, reduction of crop diversity.

- rural space, through the loss and gain of cultivated lands, land speculation, land renunciation, and hydraulic amenities.

- Adaptation, organisms may become more or less competitive, as well as humans may develop urgency to develop more competitive organisms, such as flood resistant or salt resistant varieties of rice.

\section{STEPS TO MITIGATE THE ADVERSE EFFECTS OF CLIMATE CHANGE ON AGRICULTURE}

- Increase crop diversity by inter-cropping and appropriate cropping systems/rotations/land use;

- Adopt land/water conservation agriculture methods suited to varied agro-climates

- Balanced use of biocides/chemicals;

- Increase forested area to $33 \%$ of the total geographical area;

- Increase carbon fixation in the soil by growing deep-rooted crops so as to decrease carbon foot - print;

- Use water judiciously : more crop/unit of water;

- Use less fossil fuels;

- Use more solar/wind sources of energy;

- Disseminate meteorological/climate data/information on a large - scale;

- Suggest weather-based changes in cropping systems/land uses to sustain agricultural production; 
- Encourage farmer groups to establish small weather observatories in their villages;

- Adopt use of soil-health cards widely for making fertilizer use decisions;

- Employ crop-weather models dynamically to advise farmers on improved animal/crop management for sustainable agriculture in a Decision Support System's framework.

\section{CONCLUSION}

Whether or not we understand the impact of climate, the fact is that climate change is real. Indian agriculture is likely to suffer losses due to heat, erratic weather, and decreased irrigation availability. Adaptation strategies can help minimize negative impacts, these need research and policy support. Costs of adaptation and mitigation are unknown but likely to be high. Imposing reduction targets on agriculture is impractical \& non equitable, emission of GHG's should be reduced first. Improving resilience of food production \& minimizing the risks against aberrant weather are essential.

\section{COMPETING INTERESTS}

Authors have declared that no competing interests exist.

\section{REFERENCES}

1. IPCC. Climate change: Synthesis report. United Nations Environment Programme. 2007;Ch5:8,10.

2. Mavi HS, Singh G, Johrar OP. Climate change and wheat yield in Punjab. Proc. Symp. On climate change, Natural disasters and agricultural strategies. BAU, Beijing. 1994;58-65.

3. Fuhrer J, Egger A, Lehnherr B, Grandjean A, Tschannen W. Effects of ozone on the yield of spring wheat (Triticum aestivum L., cv. Albis) grown in open-top field chambers. Environ. Pollut. 1989;60:273289.

4. Allen LH Jr., Valle RR, Mishoe JW, Jones JW, Jones PH. Soybean leaf gas exchange responses to $\mathrm{CO} 2$ enrichment. Soil Crop Sci. Soc. Fla. Proc. 1990;49:192198.

5. Abrol YP, Bhagga AP, Wattal AP. Impact of rise in temperature on the productivity of wheat in India. Proc. Symp. On impact of global warming on photosynthesis and plant productivity. Oxford \& IBH. 2000;551552.

6. Houghton JT, Collander BA, Ephraums JJ. (Eds.). Climate change - The IPCC scientific assessment. Cambridge University Press, Cambridge. 1999;135.

7. Emanuel WR, Shugart HH, Stevenson MP. Climatic change and the broad-scale distribution of terrestrial ecosystem complexes. Climatic Change. 1985;7:2943.

8. Allen LH Jr., Baker JT, Albrecht SL, Boote $\mathrm{KJ}$, Pan D, Vu JCV. Carbon dioxide and temperature effects on rice. In: Climate Change and Rice. Peng S, Ingram KT, Neue HU, Ziska LH. (Eds.). SpringerVerlag, Berlin, Heidelberg. 1995;256-277.

9. Singh KN. Evaluation of CERES rice model under temperate conditions of Kashmir valley. Cereal Research Communication. 2007;35:1723-1731.

10. Allen LH Jr., Bisbal EC, Boote KJ, Jones $\mathrm{PH}$. Soybean dry matter allocation under subambient and superambient levels of carbon dioxide. Agron. J. 1991;83:875-883.

11. Baker JT, Allen LH Jr., Boote KJ, Jones P, Jones JW. Response of soybean to air temperature and carbon dioxide concentration. Crop Sci. 1989;29:98-105.

12. Campbell WJ, Allen LH Jr, Bowes G. Effects of $\mathrm{CO} 2$ concentration on rubisco activity, amount, and photosynthesis in soybean leaves. Plant Physiol. 1988; 88:1310-1316.

13. Allen LH Jr, Bisbal EC, Boote KJ, Jones $\mathrm{PH}$. Soybean dry matter allocation under subambient and superambient levels of carbon dioxide. Agron. J. 1991;83:875-883.

14. Allen LH Jr., Boote KJ, Jones JW, Jones $\mathrm{PH}$, Valle RR, Acock B, Rogers $\mathrm{HH}$, Dahlman RC. Response of vegetation to rising carbon dioxide: Photosynthesis, biomass, and seed yield of soybean. Global Biogeochemical Cycles. 1987;1:114.

15. Baker JT, Allen LH Jr, Boote KJ. Temperature effects on rice at elevated CO2 concentration. J. Exp. Bot. 1992b; 43:959-964.

16. Satake $T$, Yoshida S. High temperature induced sterility in indica rices at flowering. Japan. J. Crop Sci. 1978;47:6-17.

17. Yoshida S. Fundamentals of rice crop science. International Rice Research Institute, Los Baños, Philippines; 1981. 
18. Baker JT, Allen LH Jr, Boote KJ. Response of rice to $\mathrm{CO} 2$ and temperature. Agric. For. Meteorol. 1992a;60:153-166.

19. Houghton JT, Collander BA. Ephraums JJ. (Eds.). Climate change - The IPCC scientific assessment. Cambridge University Press, Cambridge. 1999;135.

20. Asana RD, Williams RF. The effect of temperature stress on grain development in wheat. Aust. J. Agric. Res. 1995;16:113.

21. Hundal SS, Kaur P. Climate change and its impact on crop productivity in Punjab, India. Climate Variability and Agriculture. 1996;58: 163-165.

22. Tevini M. UV-B radiation and ozone depletion. Effects on humans, animals, plants, microorganisms, and materials. Lewis, Boca Raton, Florida; 2001.

23. Allen $\mathrm{LH} \mathrm{Jr}$, Boote $\mathrm{KJ}$, Jones JW, Jones $\mathrm{PH}$, Valle RR, Acock B, Rogers $\mathrm{HH}$, Dahlman RC. Response of vegetation to rising carbon dioxide: Photosynthesis, biomass, and seed yield of soybean. Global Biogeochemical Cycles. 1987;1:114.

24. Baker JT, Allen LH Jr, Boote KJ, Jones P, Jones JW. Response of soybean to air temperature and carbon dioxide concentration. Crop Sci. 1989;29:98105.

25. Campbell WJ, Allen LH Jr, Bowes G. Effects of $\mathrm{CO} 2$ concentration on rubisco activity, amount and photosynthesis in soybean leaves. Plant Physiol. 1988; 88:1310-1316.

26. Baker JT, Allen LH Jr. Assessment of the impact of rising carbon dioxide and other potential climate changes on vegetation. Environ. Pollut. 1994;83: 223-235.
27. Rowland-Bamford AJ, Allen LH Jr, Baker JT, Bowes G. Acclimation of rice to changing atmospheric carbon dioxide concentration. Plant Cell Environ. 1991; 14:577-583.

28. Baker JT, Allen LH Jr. Assessment of the impact of rising carbon dioxide and other potential climate changes on vegetation. Environ. Pollut. 1994;83:223-235.

29. Baker JT, Allen LH Jr, Boote KJ, Jones P, Jones JW. Response of soybean to air temperature and carbon dioxide concentration. Crop Sci. 1989;29:98-105.

30. Baker JT, Allen LH Jr. Effects of CO2 and temperature on rice: A summary of five growing seasons. J. Agric. Meteorol. (Japan). 1993b;48:575-582.

31. Baker JT, Allen LH Jr. Assessment of the impact of rising carbon dioxide and other potential climate changes on vegetation. Environ. Pollut. 1994;83:223-235.

32. Baker JT, Allen LH Jr, Boote KJ. Potential climate change effects on rice: Carbon dioxide and temperature. In: Climate change and agriculture: Analysis of Potential International Impacts. Rosenzweig C, Harper LA, Hollinger SE, Jones JW, Allen LH Jr. (Eds.). ASA Special Pub. No. 59, American Society of Agronomy, Madison, Wisconsin. 1995; 31-47.

33. Baker JT, Allen LH. Jr, Boote KJ, Pickering NB. Assessment of rice responses to global climate change: $\mathrm{CO} 2$ and temperature. In: Terrestrial Ecosystem Response to Elevated CO2. Koch GW, Mooney HA (Eds.). Physiological Ecology Series, Academic Press, San Diego. 1996;265-282.

(c) 2017 Lone et al.; This is an Open Access article distributed under the terms of the Creative Commons Attribution License (http://creativecommons.org/licenses/by/4.0), which permits unrestricted use, distribution, and reproduction in any medium, provided the original work is properly cited.

Peer-review history:

The peer review history for this paper can be accessed here: http://sciencedomain.org/review-history/19491 